\title{
Perlindungan Hukum Kesatuan Masyarakat Hukum Adat Dalam Pengelolaan Pariwisata Berbasis Kearifan Lokal
}

\author{
Ni Ketut Sari Adnyani ${ }^{*}$ \\ 1Universitas Pendidikan Ganesha, Indonesia \\ *e-mail: niktsariadnyani@gmail.com
}

Article history: Received 13 April 2021; Accepted 14 July 2021; Available online 31 August 2021

\begin{abstract}
Abstrak
Penelitian ini bertujuan untuk mengetahui mengenai dinamika perlindungan hukum masyarakat hukum adat di Provinsi Bali, eksistensi masyarakat hukum adat dalam pengelolaan kawasan wisata, sistem bagi hasil dalam pengelolaan yang adil bagi masyarakat hukum adat dan juga bagi kepentingan pemerintah daerah. Jenis penelitian hukum empiris yang mendeskripsikan dan menganalisa dinamika perlindungan hukum tehadap kesatuan masyarakat hukum adat dalam pengelolaan kawasan wisata. Hasil penelitian menunjukkan bahwa perlindungan hukum terhadap kesatuan masyarakat hukum adat di Provinsi Bali dalam pengelolaan kawasan wisata hanya dapat dilakukan melalui pengakuan terhadap hak dan kewajibannya. Eksistensi kesatuan masyarakat hukum adat dalam pengelolaan kawasan wisata mempunyai hukum pengelolaan kawasan wisata yang dituangkan dalam peraturan daerah Provinsi Bali yaitu Perda No. 2 Tahun 2012 dan awig-awig desa adat yang mengatur wilayah (wewidangan) desa adat setempat. Pengelolaan yang adil dilakukan dengan mengintegrasikan konsep-konsep pengelolaan yang disepakati. Pemerintah Daerah Provinsi Bali wajib tetap memberikan ruang pengakuan desa adat sebagai wujud perlindungan hukum pengelolaan kawasan pariwisata.
\end{abstract}

\section{Abstract}

This study aims to determine the dynamics of legal protection for customary law communities in Bali Province, the existence of customary law communities in the management of tourist areas, the profit-sharing system in proper management for customary law communities, and the interests of local people governments. This type of empirical legal research describes and analyzes the dynamics of legal protection against indigenous peoples in managing tourist areas. The results showed that the legal protection of customary law communities in Bali Province in managing tourist areas could only be done by recognizing their rights and obligations. The existence of customary law community units in the management of tourist areas has a tourism area management law outlined in the regional regulation of Bali Province, namely Perda No. 2/2012 and awig-awig adat village, which regulates the area (wewidangan) of traditional local villages. Fair management is carried out by integrating agreed management concepts. The Regional Government of Bali Province is obliged to continue providing space for recognizing traditional villages as a form of legal protection for the management of tourism areas.
Kata Kunci:

Desa Adat; Pariwisata;

Pengakuan;

Perlindungan

Keywords:

Traditional Village; Tourism; Recognition; Protection 


\section{Pendahuluan}

Negara memberikan pengakuan dan penghormatan terhadap Kesatuan Masyarakat Hukum Adat (KMHA) Hal ini di perkuat berdasarkan hasil kajian dari (Thontowi, 2013),dasar pertimbangan status pengakuan KMHA, diantaranya: Pertama, KMHA saat ini telah memperoleh status yuridis konstitusional yang kuat sebagaimana diatur dalam Pasal 18 B ayat (2) dan Pasal 28 I ayat (3) UUD NRI 1945(Indonesia, 1945) dan diperkuat oleh adanya jaminan yuridis dari beberapa undang-undang sektoral yang mengatur hak-hak tradisionalnya. Kedua, rumusan KMHA tidak terbatas pada persoalan hak, kewajiban, pemilikan dan penguasaan terhadap benda-benda bergerak dan non bergerak, materiel dan non-materiel, akan tetapi dapat mencakupperlindungan terhadap hak-hak cipta masyarakat tradisional. Ketiga, penguatan status KMHA dan hak-hak tradisional akan menjadi kuat jika Pemerintah Pusat menjabarkannya ke dalam peraturan hukum yang lebih konkret.

KMHA sebagai subyek hukum, obyek hukum dan wewenang masyarakat adat sebagai berikut: KMHA di Indonesia merupakan masyarakat atas kesamaan territorial (wilayah), Geneologis (keturunan) dan teritorial-geneologis, (wilayah dan keturunan), sehingga terdapat keanekaragaman bentuk masyarakat adat dari suatu tempat ketempat lainnya (Abdurrahman, 2007).

Lebih lanjut penghormatan terhadap nilai-nilai kearifan lokal KMHA, juga diatur dalam Pasal 2 Undang-Undang Nomor 32 Tahun 2009 tentang Perlindungan dan Pengelolaan Lingkungan Hidup (UUPPLH)(Negara Republik Indonesia, 2009), bahwa perlindungan dan pengelolan lingkungan hidup berdasarkan asas-asas ekoregion dan asas kearifan lokal. Dalam penjelasan umum diuraikan bahwa yang dimaksud asas ekoregion adalah perlindungan dan pengelolaan lingkungan hidup dengan memperhatikan karakteristik sumber daya alam, ekosistem, kondisi geografis, budaya masyarakat setempat, dan kearifan lokal. Sedangkan asas kearifan lokal adalah perlindungan dan pengelolaan lingkungan hidup harus memperhatikan nilai-nilai luhur yang berlaku dalam kehidupan masyarakat. Akan tetapi, dalam penyelenggaraan penataan ruang penguatan dan eksistensi masyarakat beserta kearifan lokalnya tidak serta merta diatur dalam Undang-Undang Perencanaan Ruang (UUPR)(Negara Republik Indonesia, 2007), menunjukkan terjadi disharmonisasi antara peraturan peundang-undangan yang berkaitan dengan pengendalian pemanfaatan ruang dan lingkungan hidup yaitu UUPR dkan UUPPLH.

Pada hakikatnya pengendalian pemanfaatan ruang berkaitan erat dengan nilai-nilai kearifan lokal yang melingkupi KMHA. Beberapa bentuk kerifan lokal termasuk hukum adat, nilai-nilai budaya dab kepercayaan yang ada sangat relevan untuk diaplikasikan ke dalam proses atau kaidah perencanaan dan pembangunan wilayah atau kawasan. Nilai-nilai kearifan lokal tersebut salah satunya terdapat di Provinsi Bali. Misalnya adanya pengakuan UNESCO tehadap keberadaan subak mencerminkan beberapa hal, antara lain: (1) pengakuan terhadap eksistensi lembaga subak, (2) lembaga subak yang menerapkan filosofi Tri Hita Karana, (3) lembaga subak yang ada di Bali dalam wujud bentang alam, adalah lanskap yang berisikan muatan aktivitas budaya (Windia, 2013).

Merujuk pada indikator nilai-nilai kearifan lokal di atas, sistem kearifan lokal yang tercermin dalam sistem pengetahuan dan teknologi lokal di berbagai daerah nusantara secara dominan masih diwarnai nilai-nilai adat seperti tampak dari cara-cara melakukan prinsipprinsip konservasi, manajemen dan eksploitasi pemanfaatan ruang. Rujukan teori yang digunakan adalah teori Negara hukum (Tamanaha, 2004), keadilan substantif dan formal dalam pengelolaan pariwisata berbasis kearifan local penting diaplikasikan. Proses panjang yang dilakukan masyarakat adat untuk berinteraksi dan beradaptasi dengan lingkungan melahirkan kemampuan dalam mengembangkan cara untuk mempertahankan hidup melalui sistem nilai, pola hidup, sistem kelembagaan,yang disesuaikan dengan lingkungannya, (Safa'at, 2013). Kearifan lokal di sini menitikberatkan pada perwujudan implementasi artikulasi dan 
pengejawantahan serta bentuk pengetahuan tradisional yang dipahami oleh manusia atau masyarakat yang berinteraksi dengan alam sekitarnya termasuk dalam pemanfaatan ruang pada kawasan pariwisata.

Tanpa disadari, limbah industri pariwisata juga berdampak pada pencemaran lingkungan laut. Ditinjau dari segi ekonomi dan sosial, pengerusakan karang ini akan menurunkan pendapatan dan kesejahteraan masyarakat. Hal ini terjadi karena dengan rusaknya ekosistem terumbu karang maka akan berdampak terhadap terjadinya ketidakseimbangan ekosistem bahari apabila hal tersebut terjadi juga akan berdampak bagi terhambatnya pembangunan di daerah yang bersangkutan (Prasetya, 2011).

Studi tehadap penelitian terdahulu (Adnyani, 2014), menunjukkan bahwa rujukan konsep Tri Hita Karana dan kearifan lokal desa adat Nyepi Segara dapat menjadi salah satu alternatif penyadaran kepada masyarakat Nusa Penida dalam hal pelestarian lingkungan laut dari aktivitas eksploitasi dapat dijadikan spirit pembangunan pariwisata berwawasan lingkungan.

Di samping persoalan pelanggaran tata ruang kawasan yang dilanggar oleh investor dalam aktfitas pariwisata di sejumlah wewidangan desa adat di Bali. Penyerapan tenaga kerja lokal terutama yang berasal dari masyarakat setempat sebagai penduduk asli daerah baik dalam bidanng investasi dan pariwisata belum terakomodasi secara lebih terperinci. Pentingnya pengaturan mengenai tenaga kerja lokal bidang pariwisata selain sebagai upaya untuk mensejahterakan masyarakat setempat juga untuk mewujudkan amanah dari konstitusi dan Pasal 26 hurf g UU kepariwisataan secara tersirat bahwa "setiap pengusaha pariwisata berkewajiban untuk memberikan kewajiban dari masyarakat setempat perlu diatur secara lebih terperinci. Berdasarkan beberapa permasalahan pengelolaan kawasan pariwisata di Bali menjadi penting mengkaji kembali perlindungan hukum KMHA. Untuk menjawab permasalahan digunakan beberapa konsep dan teori yakni teori pengakuan, teori kepastian hukum, teori pluralism hukum. Konsep yang dijadikan acuan dalam penelitian ini adalah konsep KMHA, konsep pariwisata dan konsep pembangunan berkelanjutan.

Rencana pemecahan masalah dalam penelitian ini yaitu diantaranya: (1) melakukan studi kepustakaan terhadap sejumlah peraturan perundang-undangan tentang kepariwisataan budaya Bali, penataan ruang wilayah, desa adat dan awig-awig serta melakukan tahapan penelitian mulai observasi, wawancara terhadap informan yang berkompeten menggali infomasi seputar dinamika perlindungan hukum masyarakat hukum adat di Provinsi Bali. (2) Peneliti menganalisis dan mengkaji eksistensi masyarakat hukum adat dalam pengelolaan kawasan wisata, sehingga diperoleh titik temu tentang partisipasi dan keteribatan desa adat selama ini dalam pengelolaan pariwisata di wilayah teritorial desa adat. (3) Melakukan penelusuran terhadap sejumlah dokumen hukum maupun kerjasama kemitraan antara pemerintah daerah dan desa adat tentang sistem bagi hasil dalam pengelolaan yang adil bagi masyarakat hukum adat dan juga bagi kepentingan pemerintah daerah.

Penelitian ini bertujuan untuk mengetahui mengenai dinamika perlindungan hukum masyarakat hukum adat di Provinsi Bali, eksistensi masyarakat hukum adat dalam pengelolaan kawasan wisata, sistem bagi hasil dalam pengelolaan yang adil bagi masyarakat hukum adat dan juga bagi kepentingan pemerintah daerah Penelitian ini bertujuan untuk mengetahui mengenai dinamika perlindungan hukum masyarakat hukum adat di Provinsi Bali, eksistensi masyarakat hukum adat dalam pengelolaan kawasan wisata, sistem bagi hasil dalam pengelolaan yang adil bagi masyarakat hukum adat dan juga bagi kepentingan pemerintah daerah.

\section{Metode}

Jenis penelitian pada penelitian ini adalah yuridis empiris mengarah pada jenis penelitian praktik penerapan hukum di lapangan (field research). Adapun jenis data yang telah peneliti 
amati dan dilakukan pengkajian dalam penelitian adalah berfokus pada perlindungan hukum KMHA dalam pengelolaan kawasan pariwisata, dengan mempertimbangkan keberlangsungan keberadaan desa adat sebagai tiang penyangga melakukan partisipasi dan kontrol terhadap rutinitas pariwisata di kawasan territorial desa adat setempat.

Rancangan penelitian ini adalah bersifat yuridis normatif dengan pendekatan penelitian sosio ekonomi KMHA di Provinsi Bali. Secara yuridis empiris , pengkajian perlindungan hukum KMHA dalam pengelolaan kawasan pariwisata penting dilakukan. Pendekatan penelitian diharapkan dapat memberikan gambaran tentang perkembangan kehidupan sosio ekonomi masyarakat desa adat setempat.

Penelitian ini dilakukan di Provinsi Bali. Dipilihnya lokasi ini sebagai objek penelitian karena ada beberapa permasalahan yang menunjukkan bahwa pengelolaan kawasan pariwisata seperti di Pantai kuta, tanah Lot, Tirta Empul, Danau Batur, kertha Gosa, Pantai Tulambe, Jati Luwih, Lovina dan Taman Nasional Bali Barat belum melibatkan peran desa adat secara optimal. Imbas dari minimnya pelibatan desa adat berpengaruh terhadap terbatasnya ruang gerak desa adat untuk melakukan partisipasi dalam pengelolaan kawasan pariwisata di wilayah territorial (wewidangan) desa adat setempat.

Subjek penelitian ini diantaranya meliputi: prajuru desa adat, krama desa adat,pelaku jasa pariwisata, tokoh masyarakat, dan aparat desa dinas wilayah Provinsi Bali yang dijadikan saampel penelitian seperti wilayah Bali bagian Tengah, Timur, Barat, Utara, Selatan. Penentuan informan yang menjadi subjek dalam penelitian ini ditentukan secara purposive.

Objek dalam penelitian ini adalah kehidupan sosial ekonomi masyarakat desa adat di kawasan pariwisata. Penelitian ini berfokus pada perlindungan hukum desa adat dalam pengelolaan kawasan pariwisata dengan mempertimbangkan keberlangsungan eksistensi kebertahanan desa adat.

Adapun teknik pengumpulan data yang dipergunakan oleh peneliti adalah sebagai berikut: Teknik Observasi. Sutardi (2018), observasi adalah: "pengamatan dan pencatatan yang dilakukan secara sistematis terhadap fakta, data dan gejala yang diteliti. Dalam arti luas observasi adalah pengamatan yang dilakukan dengan semua indera dan pencatatan sistematis terhadap semua fakta, data dan gejala baik secara langsung maupun tidak langsung dalam waktu dan tempat tertentu di mana data fakta dan gejala tersebut ditemukan".Jadi, dalam observasi ini dapat dilakukan dengan dua cara yaitu: (1) Observasi langsung, maksudnya bahwa peneliti mengamati secara langsung ke objek penelitian dan ikut berpartisipasi dengan subjek penelitian, dan (2) Observasi tidak langsung, yaitu bahwa peneliti di dalam mengamati serta mencatat gejala-gejala subjek yang diteliti tidak ikut berpartisipasi di dalam subjek yang diteliti. Di dalam penelitian yang peneliti lakukan untuk mengumpulkan data menggunakan observasi secara langsung yang artinya peneliti aktif mengamati, memeriksa, dan menulis secara teratur dari gejala-gejala atau keadaan yang dijumpai dalam kaitannya dengan perlindungan hukum desa adat dalam pengelolaan kawasan pariwisata di Provinsi Bali.

Teknik Interview yang dimaksud dengan teknik interview adalah:"Suatu proses tanya jawab secara lisan, di mana dua orang atau lebih berhadapan secara fisik, yang satu sama lainnya saling dapat melihat muka yang lain dan mendengarkan dengan telinga sendiri suaranya"(Soekanto, 2012). Dengan menggunakan teknik interview ini tanya jawab yang dilakukan secara lisan antara dua orang atau lebih guna mendapatkan data-data yang diinginkan, diharapkan akan terjadi interaksi aktif antara objek dan subjek peneliti sehingga data yang diperoleh betul-betul berguna untuk mendukung penyusunan penelitian.

Teknik Pencatatan Dokumen, teknik ini digunakan untuk mendapatkan data dengan jalan mengamati, memperhatikan dan mencatat dokumen-dokumen, laporan-laporan, data statistik yang ada kaitannya dengan topik penelitian. Berdasarkan uraian di atas, yang tergolong di dalam pencatatan dokumen dalam penelitian ini adalah sebagai berikut: segala macam bahan hukum 
yang meliputi: Peraturan Daerah Provinsi Bali No. 2 Tahun 2012 tentang Kepariwisataan Budaya Bali(Bali, 2012); Perda Provinsi Bali No. 4 Tahun 2019 tentang Desa Adat(Bali, 2019), awig-awig, kebijakan kepariwisataan, Peta Administrasi Pemerintah Desa yang dijadikan sampel penelitian dan Kuisioner tentang kehidupan sosial ekonomi desa adat di kawasan pariwisata di wilayah desa adat.

Teknik analisa data yang diterapkan dalam penelitian ini adalah analisa data deskriftif kualitatif, mengintegrasikan data temuan di lapangan menurut perkembangan terakhir sehingga dapat memberikan gambaran tentang perkembangan situasi kehidupan sosial ekonomi desa adat dalam rangka memperoleh perlindungan hukum dalam pengelolaan kawasan pariwisata di Provinsi Bali .

\section{Hasil dan Pembahasan}

\section{Gambaran Umum Kepariwisataan Provinsi Bali}

Pariwisata sampai saat ini masih merupakan motor penggerak ekonomi Bali. Sehingga cerah atau muramnya kondisi ekonomi provinsi yang dikenal dengan julukan Pulau Dewata ini akan sangat bergantung dari kinerja pariwisata secara umum. Pulau Bali telah menjadi destinasi wisata yang dikenal di dunia internasional, salah satunya adalah Pantai Kuta. Dengan menjadi tuan rumah penyelenggara Pertemuan Tahunan International Monetery Fund (IMF)-World Bank 2018 dapat memberi dampak positif bagi sektor pariwisata di Pulau Dewata, yang diperkirakan akan menaikkan kunjungan wisatawan mancanegara (wisman) ke Provinsi dengan ibu kota Denpasar ini. Kunjungan Wisatawan Mancanegara ke Bali 2018 Mencapai 72\% dari Tahun Sebelumnya, seperti terlihat pada Gambar 1.

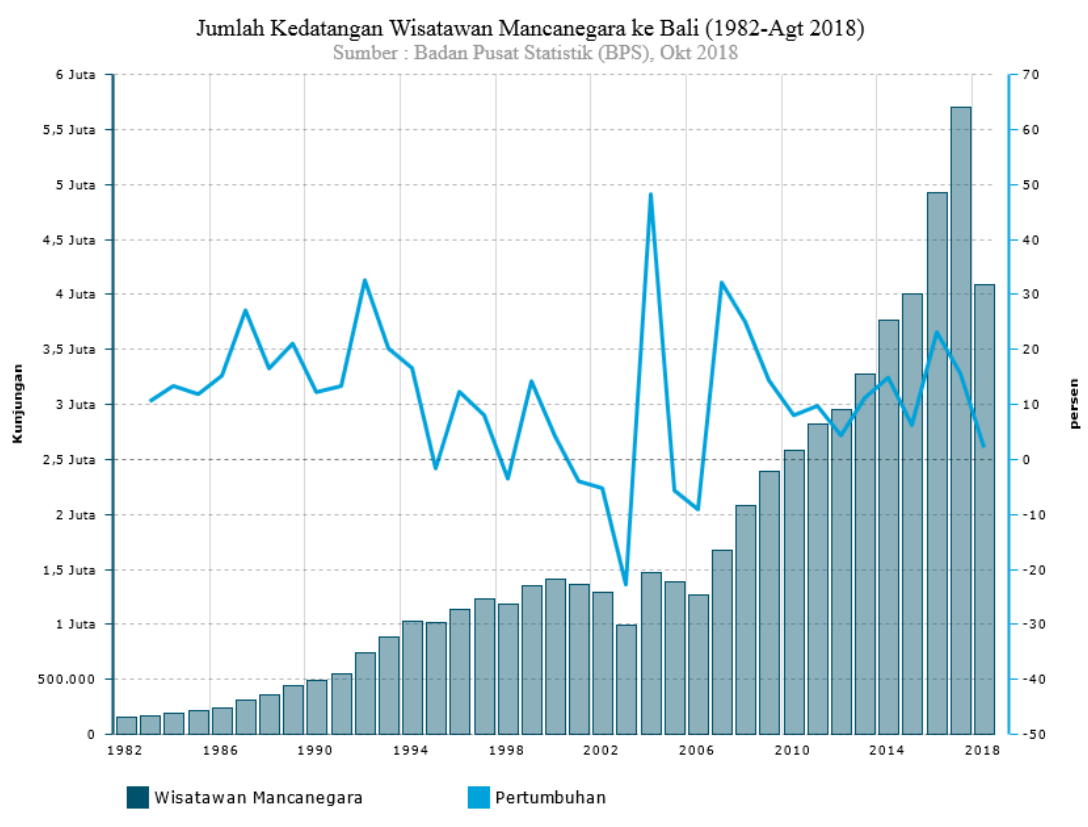

Gambar 1. Kunjungan Wisatawan Mancanegara ke Bali Sumber: BPS, 2018

Badan Pusat Statistik mencatat kedatangan wisman yang datang ke Pulau Bali periode Januari-Agustus 2018 mencapai $\pm 4,09$ juta kunjungan naik $\pm 2,15 \%$ dibanding periode yang sama tahun sebelumnya. Jumlah tersebut mencapai $\pm 72 \%$ dari total kunjungan wisman 
sepanjang tahun lalu. Berdasarkan asal negara, wisman dari Tiongkok yang paling banyak berkunjung ke Bali, yaitu mencapai \pm 962 ribu kemudian diikuti dari Australia \pm 763 ribu kunjungan. Kunjungan wisman ke Bali mencapai puncaknya pada 2017 dan pertumbuhan tertinggi dicapai pada 2004 seperti terlihat pada grafik Tingkat Penghunian Kamar (TPK).

TPK hotel berbintang di Provinsi Bali pada Agustus tahun ini mencapai $\pm 73,83 \%$. Adapun yang terbesar dicatat oleh hotel dengan klasifikasi bintang 4, yakni mencapai $\pm 79,18 \%$ sedangkan yang terendah hotel berbintang 1 yang hanya mencapai $\pm 55,26 \%$. Sementara ratarata menginap tamu hotel adalah $\pm 2,83$ hari dan yang paling lama di hotel bintang 5 mencapai $\pm 3,14$ hari.

Dari lansir data yang telah diperoleh menunjukkan peningkatan perkembangan pariwisata di Bali berhubungan dengan keputusan untuk sektor publik dan swasta, seperti: infrastruktur, transportasi, akomodasi, promosi, dan layanan lainnya. Oleh karena itu, pemerintah dan industri membutuhkan dukungan desa adat dalam memfasilitasi kunjungan wisatawan mancanegara terebut. Partisipasi desa adat dibutuhkan untuk perencanaan kebijakan perlindungan hukum kawasan pariwisata yang efektif.

\section{Kawasan Pariwisata di Bali}

Bali adalah sebuah pulau di Indonesia yang dikenal karena memiliki pegunungan berapi yang hijau, terasering sawah yang unik, pantai, dan terumbu karang yang cantik. Terdapat banyak tempat wisata religi seperti Pura Uluwatu yang berdiri di atas tebing. Di Selatan, kota pesisir pantai Kuta menawarkan wisata hiburan malam yang tak pernah sepi, sementara Seminyak, Sanur, dan Nusa Dua dikenal dengan suguhan resort yang populer. Pulau Bali juga dikenal sebagai tempat untuk relaksasi dengan yoga dan meditasi.

Pulau Bali hanya satu namun memiliki banyak pilihan tempat wisata yang menawarkan daya tarik dan keunikan tersendiri. Selain tempat wisata, aktivitas liburan seru di Bali juga ada banyak pilihan. Pastinya akan dapat memenuhi kriteria wisatawan yang berbeda-beda. Hal tersebut, membuat pulau Bali menjadi salah satu destinasi wisata favorit di Indonesia.

Berikut ini daftar nama wilayah pariwisata di pulau Bali favorit wisatawan, baik wisman maupun wisatawan Indonesia. seperti di Pantai kuta, tanah Lot, Tirta Empul, Danau Batur, kertha Gosa, Pantai Tulambe, Jati Luwih, Lovina dan Taman Nasional Bali Barat, sejumlah nama dari wilayah pariwisata di Bali tersebut, terdapat daya tarik dan keunikan tiap kawasan pariwisata di Bali.

\section{Desa Adat dalam Pengelolaan Kawasan Pariwisata}

Menurut (Utama, 2007), local genius atau kearifan lokal yang dapat dijumpai pada lingkup sosial budaya desa adat pada dasarnya merupakan kemampuan untuk mengendalikan serta memberikan arah perkembangan kehidupan masyarakat setempat. .Ada beberapa ciri yang ditemukan pada kearifan lokal suatu masyarakat, seperti berkmampuan bertahan tehadap budaya luar, mampu mengakomodasi unsur-unsur budaya asing, mampu mengintegrasikan budaya luar ke dalam budaya asli, mampu mengendalikan dan mengarahkan perkembangan budaya masyarakat, tebina secara komulatif, terbentuk evolusioner, serta tidak selamanya tampak jelas secara lahiriah. Dengan demikian, kearifan lokal desa adat mempunyai kemampuakn untuk mengendalikan serta memberikan arah perkembangan kehidupan masyarakat setempat. Ada beberapa cirri yang ditemukan pada kearifan lokal suatu KMHA.

Berdasarkan inidikator tersebut di atas, dapat dipahami bahwa kearifan lokal desa adat merupakan hasil proses berpikir untuk menyelesaikan permasalahan yang perumusannya lebih 
ditekankan pada aspek lokal dan bukan pada aspek waktunya, yang dapat disimpulkan oleh (Wija Atmaja, 2016), sebagai berikut.

1) Kearifan lokal desa adat lebih menekankan kepada konteks wilayah, tempat atau lokalitas dan kearifan tersebut sehingga kearifan lokal tidak harus merupakan kearifan yang diwariskan dari generasi ke generasi (kearifan tradisional) .

2) Kearifan lokal lahir dari proses berpikir satu komunitas dalam merespon permasalahan yang dihadapi dan bersumber pada pengetahuan dari generasi sebelumnya yang dipandang masih sesuai ataupun dari pengalaman-pengalaman.

3) Kearifan tradisional (lama) diperoleh dari generasi-generasi sebelumnya secara lisan atau melalui contoh tindakan, yang memiliki kekuatan seperti hukum maupun tidak. Sedangkan, kearifan kontemporer (kini) adalah perangkat pengetahuan yang baru saja muncul dalam suatu komunitas.

Kehidupan sosial budaya desa adat merupakan substansi pariwisata, di mana semestinya desa adat memperoleh ruang dalam pengelolaannya. Sebagai subyek hukum desa adat juga memperoleh pengakuan untuk berpartisipasi.

\section{Dinamika Perlindungan Hukum Masyarakat Hukum Adat pada Pengelolaan Pariwisata Di Provinsi Bali}

Berbagai peraturan perundang-undangan dalam berbagai sektor secara implisit mengakui keberadaan masyarakat hukum adat. Bahwa pengakuan saja oleh pemerintah tidaklah cukup untuk bisa melindungi keberadaan masyarakat hukum adat di Indonesia. Bahwa UUD RI Tahun 1945 telah dengan tegas memberikan amanat bahwa keberadaan masyarakat hukum adat dan kearifan lokalnya akan diatur dalam undang-undang. Hal ini mengamanatkan adanya peraturan pelaksana hingga tingkat paling bawah seperti halnya peraturan daerah (Perda) menjadi sangat urgent untuk disusun sehingga masyarakat hukum adat yang berada di daerah memiliki payung hukum dan pemerintah daerahlah yang lebih tahu tentang masyarakat dan kearifan lokal yang dimiliki di wilayahnya (Sari, 2020).

Pemerintah Daerah, harus memiliki pemahaman yang mendalam tentang pentingnya menyusun dan mengimplementasikan kebijakan yang baik dalam kegiatan kepariwisataan (Marhaendra Wija Atmaja, 2016). Kepariwisataan tidak hanya berkaitan dengan fenomena orang yang melakukan perjalanan, tetapi juga berdampak terhadap masalah-masalah seperti pencapain tujuan sosial dan budaya, kebijakan luar negeri, pembangunan ekonomi, perlindungan lingkungan hidup dan perencanaan pembangunan yang berkelanjutan (Antarikasa, 2016). Perbedaan substansi kajian penelitian terdahulu dengan penelitian dari peneliti yaitu terletak pada objek kajian dimana objek kajian peneliti lebih difokuskan pada pengakuan desa adat dalam pembangunan pariwisata berkelanjutan dengan mengkaji produk hukum daerah Pemerintah Provinsi Bali seperti Perda Kepariwisataan Budaya Bali dan Perda Desa Adat.

Merujuk pada ketentuan Pasal 1 angka 14 Peraturan Daerah Provinsi Bali Nomer 2 tahun 2012 tentang Kepariwisataan Budaya Bali, menentukan: "Kepariwisataan budaya Bali adalah kepariwisataan Bali yang berlandaskan kepada kebudayaan Bali yang dijiwai oleh ajaran Agama Hindu dan falsafat Tri Hita Karana sebagai potensi utama dengan menggunakan kepariwisataan sebagai wahana aktualisasinya, sehungga terwujud hubungan timbal balik yang dinamis antara kepariwisataan dan kebudayaan yang membuat keduanya berkembang secara sinergis, harmonis dan berkelanjutan untuk dapat memberikan kesejahteraan kepada masyarakat, kelestarian budaya dan lingkungan". 
Lebih lanjut pengaturan masalah kebudayaan Bali harus memperhatikan komponen terkait satu dengan lainnya dan saling mendukung, seperti, manusia sebagai pendukung kebudayaan, dan alam sebagai wadah kebudayaan itu. Pasal 5 Peraturan Daerah Provinsi Bali Nomer 2 tahun 2012 tentang Kepariwisataan Budaya Bali, belum secara implisit mengatur bagaimana hak, kewajiban serta kewenangan yang dimiliki desa adat dalam pengelolaan Kepariwisataan Budaya Bali .

Dalam dinamika perkembangannya, desa adat yang sejak semula keberadaannya menjaga ketertiban dan kedamaian kehidupan, menjaga keseimbangan dan keharmonisan berbagai kepentingan warga yang ada di dalam dirinya, kini harus menghadapi kenyataan pahit, menahan langkah dengan penuh perhitungan dalam menggunakan hak dan kewenangan dalam mengatur wilayahnya sebagai akibat intrusi berbagai nilai kehidupan masyarakat modern. Keadaan ini dirasakan secara penuh oleh beberapa desa adat dalam berbagai bentuknya seperti: cara berfikir, cara bersikap, cara berperilaku warga desa adat, perubahan situasi sosial, peningkatan ketegangan dan konflik sosial, dan hambatan serius dalam menggunakan hak-hak sejarah dan kulturalnya seperti dalam mengelola dan mengatur wilayahnya. Disinilah letak persoalan karena krama desa adat merasa tidak mendapatkan keadilan sehingga perlu dilakukan pengkajian ulang terhadap substansi kebijakan berkenaan dengan hak dan kewajiban desa adat dalam pengelolaan kawasan pariwisata di wilayah territorial (wewidangan) desa adat.

\section{Eksistensi Masyarakat Hukum Adat Dalam Pengelolaan Kawasan Wisata}

Desa adat sebagai KMHA yang masih hidup, keberadaan dan hak-hak tradisional yang dimiliknya dilindungi oleh Konstitusi (UUD.NRI 1945). Pasal 18B ayat (2). Ini berarti konstitusi mengakui bahwa desa adat mempunyai kemampuan hukum (legal capacity) untuk mempertahankan hak-hak tradisionalnya di hadapan pengadilan. Kemampuan hukum tersebut bukan hanya terhadap perbuatan orang perorangan tetapi juga terhadap perbuatan Negara (Putra, 2017).

Masyarakat hukum adat sebagai pendukung hukum adat memegang peranan yang sangat penting dan bersifat strategis. Pembentuk Undang-undang. Untuk mendapat hak melakukan pengelolaan kawasan pariwisata di wilayahnya, ada berberapa kriteria keberadaan masyarakat hukum adat yang harus memperhatikan kebijakan pengelola pariwisata budaya di wilayahnya termasuk pemeliharaan yang ada di bawah desa kepemilikan desa adat. Paradigma pengelolaan kepariwisataan budaya merupakan skema yang menempatkan desa pakraman sebagai pemilik atau wadah kebudayaan sebagai pelaku pengelolaan karena ada ikatan integral antara kebudayaan dengan masyarakat adat (desa adat) sebagai subjek pendukung utama.

Selaras dengan itu, penting dipenuhi unsur-unsur tersebut antara lain: Masyarakatnya masih dalam bentuk paguyuban (rechtsgemeenschap) dan bertempat tinggal di dalam wilayah hukum adat yang bersangkutan; Ada kelembagaan dalam bentuk perangkat penguasa adat (Struktur Kelembagaan Adat) yang masih berfungsi; Mempunyai wilayah hutan adat yang jelas batas-batasnya dan diakui/disepakati oleh masyarakat dan antar masyarakat hukum adat di sekitarnya; Ada pranata hukum adat yang berkaitan dengan hutan dan masih ditaati, dan masih diberlakukannya peradilan adat; Masyarakat yang bersangkutan masih melaksanakan pemanfaatan dan pemungutan hasil hutan di hutan sekitarnya untuk pemenuhan kehidupan sehari-hari dan atau masih adanya hubungan religi dan hubungan kemasyarakatan dengan hutan adatnya (Al-oun and Al-Homoud, 2008).

KMHA dalam keikutsertaannya melakukan kontrol dan akses terhadap pengelolaan pariwisata terutama di wilayah teritorial (wewidangan) desa adat, masyarakat berhak: Mengelola kawasan pariwisata yang berada dalam wilayah hukum adatnya; Mempraktekkan pengetahuan, teknologi dan kearifan setempat dalam mengelola pariwisata; Memperoleh pendampingan dan fasilitasi dari pemerintah dan atau pemerintah daerah dan LSM dalam 
rangka pemberdayaannya; Memperoleh perlindungan dari pemerintah dan atau pemerintah daerah; Berpartisipasi dalam pengurusan pariwisata dan pengawasan operasionalisasi industi pariwisata.

KMHA yang diakui keberadaannya wajib: Memelihara dan menjaga kawasan pariwisata dari kerusakan; Memanfaatkan kawasan pariwisata sesuai dengan fungsi pokoknya; Sesuai tahapan pemanfaatan kawasan pariwisata di wilayah desa adat, membayar pajak bumi dan bangunan atas lahan desa adat.

\section{Sistem Bagi Hasil Dalam Pengelolaan Yang Adil Bagi Masyarakat Hukum Adat dan Kepentingan Pemerintah Daerah}

Kewajiban yuridis konstitu-sional terkait pengakuan dan penghormatan terhadap KMHA yang dilakukan oleh pemerintah pusat dan daerah masih menjumpai berbagai kendala. Kebijakan negara terkait pelayanan publik semakin menujukan bukti keberadaan mereka sebagai kelompok minoritas diperlakukan secara diskriminatif (Thontowi, 2015).

Pertimbangan lain perlunya kebijakan pengaturan pengakuan dan perlindungan hak masyarakat hukum adat, yaitu, masyarakat hukum adat selama ini belum diakui dan dilindungi secara optimal dalam melaksanakan hak pengelolaan yang bersifat komunal, baik hak atas tanah, wilayah, budaya, dan sumber daya alam yang diperoleh secara turun-temurun maupun yang diperoleh melalui mekanisme lain yang sah menurut hukum adat setempat. Belum optimalnya pengakuan dan perlindungan hak masyarakat hukum adat yang bersifat komunal mengakibatkan munculnya konflik di masyarakat hukum adat, sehingga menimbulkan ancaman stabilitas keamanan nasional. Diharapkan lahirnya UU PPHMHA dapat mengakomodir kepentingan masyarakat hukum adat dan merekonstruksi masyarakat hukum adat sebagai subjek hukum yang bersifat khusus dan istimewa (Nugroho, I., Negara, P. D., \& Yuniar, 2018).

Merujuk pada hasil (Widiateja, 2011)menegaskan bahwa Peraturan Daerah Provinsi Bali Nomor 2 Tahun 2012 tentang Kepariwisataan Budaya Bali, memberi posisi pemerintah maupun swasta dalam pembangunan Kepariwisataan Budaya Bali, baik dalam usaha pariwisata, destinasi pariwisata, pemasaran, maupun kelembagaan kepariwisataan. Dengan demikian akan melahirkan kontruksi baru dalam sistem pengelolaan kebudayaan Bali. Pemerintah dan swasta sebagai pihak eksternal menjadi komponen aktif yang terlibat dalam pengelolaan kepariwisataan budaya Bali.

Pemerintah tidak hadir sebagai pemelihara budaya Bali melainkan sebagai pengatur dan bahkan bisa dibilang sebagai penikmat hasil pengelolaan kepariwasataan budaya Bali. Posisi ini bisa melahirkan suatu masalah dalam sistem pengelolaan kepariwisataan budaya Bali, bahkan akan terjadi kesenjangan bahkan diskoneksitas antara komunitas pemilik dan pemelihara budaya Bali dengan pihak ekternal sebagai pengatur.

Terhadap legal drafter di tingkat pemerintah daerah dan desa adat penting mengakomodasi hak dan kewajiban desa adat dalam pengelolaan kawasan pariwisata. Sinergi mutual triple helix dalam pengembangan pariwisata Bali antara Desa Dinas dan Desa Adat merupakan dua komponen yang saling terkait dan tidak dapat dipisahkan satu dengan yang lain. Dalam hal ini, Desa Adat berperan sebagai ujung tombak penghubung antar masyarakat dan pemerintah dalam rangka pelaksanaan program-program pemerintah khususnya dalam bidang pariwisata.

Beberapa potensi yang yang dimiliki oleh Desa Adat dalam menunjang pariwisata adalah, struktur pola menetap di pedesaan dilandasi oleh konsep: Tri Hita Karana, Tri Mandala, Tri Angga, dan Hulu Teben, sehingga menampilkan corak tersendiri yang khas dalam sistem kehidupan masyarakat di Bali. 
Pemberdayaan Desa Adat sebagai desa otonomi merupakan cara yang terbaik untuk mengembangkan dan meningkatkan mutu pelayanan kepada masyarakat adat dalam berbagai aspek kehidupannya baik yang menyangkut hubungan dengan Sang Hyang Widhi Wasa, dengan sesame manusia dan hubungannya dengan alam sekitarnya (Tri Hita Karana).

Keserasian hubungan antara: tata-agama dengan tata-pawongan dan tata-palemahan dalam konsep tri hita karana, memberikan perasaan hidup yang sejahtera di pedesaan. Demikian pula pembagian palemahan desa, palemahan pura dan palemahan human menjadi tiga yaitu utama mandala, madhyamandala dan nistha mandala menurut trimandala adalah serasi dengan konsep triangga dalam diri manusia yaitu: utama angga, Madhya, angga dan nistha angga. Trimandala adalah konsep yang berorientasi horizontalvertikal. Hulu-teben adalah suatu konsep yang sangat aktual dalam kehidupan masyarakat di Bali. Desa Adat memang merupakan desa yang sangat potensial dalam menunjang pariwisata di Bali, karena memiliki berbagai potensi sebagai aset pariwisata, di samping juga karena corak kepariwisataan di Bali adalah pariwisata budaya.

\section{Simpulan dan Saran}

Dinamika KMHA dalam pengelolaan kawasan pariwisata di Bali belum dijembatani oleh substansi pengaturan yang emplisit mengatur hak dan kewajiban desa adat dalam pengelolaan pariwisata di wilayah territorial (wewidangan) desa adat setempat. Pengaruhnya adalah ketidakadilan secara sosiologis dirasaan oleh desa adat. Bagi hasil yang belum proporsional membutuh.an sinergi mutual triple helix dan legal drafter untuk mengevaluasi kembali kebijakan pengelolaan kawasan pariwisata dengan pertimbangan bhwa desa adat memiliki hak sekaligus kewajiban melakukan pemberdayaan potensi pariwisata di Provinsi Bali. Kepada Legal drafter di level Perintah Daerah, disarankan agar meninjau kembali substansi pengaturan Pasal 5, Peraturan Daerah Provinsi Bali Nomor 2 tahun 2012 yang belum menghadirkan substansi hak dan kewajiban desa adat dalam pengelolaan kepariwisataan budaya di wilayah wewidangan desa adat. Tetap memberikan porsi kepada desa adat, dalam pengelolaan kawasan pariwisata dengan sistem pengelolaan, pemeliharaan yang berada di bawah otoritas otonomi desa adat. Penelitian lebih lanjut penting mengkaji pengakuan desa adat dalam mengakomodasi potensi kearifan lokal seperti tenaga kerja lokal yang dilibatkan dalam pembangunan pariwisata. Pengakuan dalam bentuk produk hukum sejeis seperti Undang-Undang Pokok Agraria dalam hal pengadaan lahan di kawasan pariwisata urgen dikaji oleh peneliti berikutnya karena dinilai memiliki relevansi dengan pengakuan KMHA sekaligus hak-hak otonomi desa adat.

\section{Ucapan terima kasih}

Ucapan terima kasih penulis sampaikan kepada FHIS Universitas Pendidikan Ganesha yang telah memfasilitasi penulis media publikasi pelaksanaan kegiatan penelitian. Penulis juga menghaturkan terima kasih kepada LPPM Undiksha, artikel ini sebagai bagian dari proses pelaksanaan Tri Dharma Perguruan Tinggi bidang Penelitian yang telah didanai melalui hibah DIPA Undiksha di bawah koordinasi LPPM Undiksha.

\section{DaftarPustaka}

Abdurrahman (2007) "Hukum Adat Dalam Perkembangan Pluralisme Hukum di Indonesia". Makassar.

Adnyani, N. K. S. (2014) 'Nyepi Segara sebagai kearifan lokal masyarakat Nusa Penida dalam pelestarian lingkungan laut', Jurnal Ilmu Sosial dan Humaniora, 3(1), p. 6.

Al-oun, S. and Al-Homoud, M. (2008) 'The Potential for Developing Community-based Tourism 
among the Bedouins in the Badia of Jordan', Journal of Heritage Tourism, 3. doi: 10.1080/1743873X.2008.9701249.

Antarikasa, B. (2016) Kebijakan Pembangunan Kepariwisataan, Pengembangan Kepariwisataan yang Berkelanjutan dan Perlindungan Kekayaan Intelektual. Malang: Intrans Publishing.

Bali, P. P. (2012) Peraturan Daerah Provinsi Bali Nomor 2 Tahun 2012 tentang Kepariwisataan Budaya Bali. Indonesia.

Bali, P. P. (2019) Perda Provinsi Bali Nomor 4 Tahun 2019 tentang Desa Adat. Indonesia.

Indonesia, N. R. (1945) Undang-Undang Dasar Negara Republik Indonesia Tahun 1945.

Marhaendra Wija Atmaja, G. (2016) Politik Pluralisme Hukum: Arah Pengakuan Kesatuan Masyarakat Hukum Adat Dengan Peraturan Daerah. Denpasar, Bali: Percetakan Bali.

Negara Republik Indonesia (2007) Undang-Undang Republik Indonesia Nomor 26 Tahun 2007 tentang Penataan Ruang. Indonesia.

Negara Republik Indonesia (2009) Undang-Undang No 32 Tahun tentang Perlindungan dan Pengelolaan Lingkungan Hidup. Indonesia.

Nugroho, I., Negara, P. D., \& Yuniar, H. R. (2018) 'The Planning And The Development Of The Ecotourism And Tourism Village In Indonesia: A Policy Review', Journal of Socioeconomics and Development, 1(1), pp. 43 (43-51).

Prasetya, I. N. D. (2011) “'Potensi dan Kondisi Terumbu Karang di Kawasan Wisata Lovina”', Jurnal Lingkungan Tropis, 6(1), p. 3.

Safa'at, R. (2013) Rekonstruksi Hukum Pangan dan Ketahanan Pangan Kedaulatan Pangan. Malang: UB Press.

Sari, N. L. A. (2020) 'Pengakuan Dan Perlindungan Hukum Terhadap Masyarakat Hukum Adat (Dalam Perspektif Negara Hukum)', Ganec Swara, 14(1), pp. 439-445 (442).

Soekanto, S. (2012) Sosiologi, Suatu Pengantar. Jakarta: Rajawali Pers.

Tamanaha, B. Z. (2004) On The Rule of Law: History, Politics, Theory. Cambridge: Cambridge University Press.

Thontowi, J. (2013) 'Perlindungan dan Pengakuan Masyarakat Adat dan Tantangannya dalam Hukum Indonesia', Jurnal Hukum Ius Quia Iustum, 20(1), pp. 21-36 (24).

Thontowi, J. (2015) 'Pengaturan Masyarakat Hukum Adat dan Implementasi Perlindungan Hakhak Tradisionalnya', Pandecta: Research Law Journal, 10(1), p. 25.

Utama, I. M. A. (2007) Hukum Lingkungan Sistem Hukum Perizinan Berwawasan Lingkungan untuk Pembangunan Berkelanjutan. Bandung: Pustaka Sutra.

Widiateja, I. G. P. (2011) Kebijakan Liberalisasi Pariwisata Konstruksi Konsep, Ragam Masalah dan Alternatif Solusi. Denpasar: Udayana University Press.

Wija Atmaja, G. M. (2016) Pluralisme Konstitusional dalam Pengakuan kesatuan Masyarakat Hukum Adat. Yogyakarta: Penerbit Andi.

Windia, W. I. (2013) '”Penguatan Budaya Subak Melalui Pemberdayaan Petani”', Jurnal kajian Bali, 3(2), p. 43.

Wyasa Putra, I. B. (2017) Landasan Teoritik Pengaturan Pelestarian Warisan Budaya: Bali sebagai Suatu Model. Denpasar, Bali: Udayana University Press. 